Reviu Akuntansi dan Bisnis Indonesia, Vol. 5 No. 2, Hlm 164-184, Desember 2021

Website: http://journal.umy.ac.id/index.php/rab

\title{
Pengaruh Tingkat Keseriusan Pelanggaran, Reporting Channel, dan Retaliasi Terhadap Niat Melakukan Whistleblowing
}

\author{
Karinna Heydy Nurhalizah; Ilham Maulana Saud \\ Program Studi Akuntansi Universitas Muhammadiyah Yogyakarta
}

\section{N F O A R T I K E L}

\section{Kata Kunci:}

Tingkat Keseriusan

Pelanggaran; Reporting

Channel; Retaliasi;

Whistleblowing

Jenis Artikel:

Penelitian Eksperimen

\section{Korespondensi:}

ilhamsaud@umy.ac.id

\section{Proses Artikel:}

Diterima 23 Juli 2021

Review 19 Agustus 2021

Review 14 September 2021

Revisi 2 Desember 2021

Revisi 8 Desember 2021

Diterbitkan Desember 2021

\section{Sitasi:}

Nurhalizah, K.H., \& Saud, I.M.

(2021). Pengaruh Tingkat

Keseriusan Pelanggaran,

Reporting Channel, dan

Retaliasi Terhadap Niat

Melakukan Whistleblowing.

Reviu Akuntansi dan Bisnis

Indonesia, 5(2), 164-184.

Link Artikel:

10.18196/rabin.v5i2.12376

\section{A B S T R A K}

\section{Latar Belakang:}

Saat ini telah banyak terjadi kecurangan seperti korupsi, pemalsuan laporan keuangan, suap menyuap, dan lain sebagainya. Adanya kasus kecurangan ini menimbulkan banyak kerugian. Oleh sebab itu maka dibutuhkan suatu kebijakan untuk mencegah maupun mengungkap adanya kecurangan salah satunya yaitu dengan menerapkan kebijakan whistleblowing. Kebijakan whistleblowing sudah diterapkan di berbagai perusahaan seperti perusahaan Telkom, Pertamina, Astra Group, Direktorat Jenderal Pajak, dan lain-lain. Namun untuk melakukan whistleblowing seseorang akan dipengaruhi oleh berbagai faktor seperti tingkat keseriusan pelanggaran, reporting channel, dan retaliasi.

\section{Tujuan:}

Penelitian ini bertujuan untuk menganalisis pengaruh tingkat keseriusan pelanggaran (rendah dan tinggi), reporting channels (anonymous reporting channel dan non-anonymous reporting channel), dan retaliasi (rendah dan tinggi) terhadap niat melakukan whistleblowing.

\section{Metode Penelitian:}

Pendekatan pada penelitian ini menggunakan eksperimen 2x2x2 between subjects effects dengan 165 subjek penelitian. Subjek dalam penelitian ini adalah mahasiswa S1 Program Studi Akuntansi Universitas Muhammadiyah Yogyakarta. Sampel dalam penelitian ini dipilih menggunakan metode purposive sampling. Alat analisis yang digunakan adalah Analysis of Variance (ANOVA).

\section{Hasil Penelitian:}

Hasil penelitian menunjukkan bahwa tingkat keseriusan pelanggaran tidak berpengaruh positif signifikan terhadap niat melakukan whistleblowing, adanya anonymous reporting channel lebih efektif untuk meningkatkan niat seseorang melakukan whistleblowing, dan retaliasi rendah lebih efektif untuk meningkatkan niat seseorang melakukan whistleblowing. Dalam kondisi tingkat keseriusan pelanggaran tinggi, anonymous reporting channel, dan retaliasi rendah lebih efektif dalam meningkatkan niat seseorang untuk melaporkan tindakan pelanggaran.

\section{Keterbatasan Penelitian:}

Responden pada penelitian hanya terbatas mahasiswa akuntansi FEB UMY angkatan 2018 di mana mahasiswa belum memahami kondisi sesungguhnya yang terjadi dalam dunia kerja.

\section{Keaslian/Novetly Penelitian:}

Penelitian ini merupakan replikasi dari penelitian terdahulu dengan mengganti variabel financial reward dengan tingkat keseriusan pelanggaran dan mengubah subyek serta lokasi penelitian. 


\section{PENDAHULUAN}

Memiliki sistem pemerintahan yang bersih dan aman merupakan cita-cita semua negara salah satunya Indonesia. Sistem pemerintahan dan bernegara yang baik merupakan cita-cita negara yang terdapat pada UUD 1945 (alinea empat). Namun hal tersebut masih belum bisa terealisasikan karena dilihat saat ini masih terdapat banyak kasus yang menyimpang seperti kecurangan yang dilakukan oleh pemerintah maupun swasta. Banyaknya kecurangan kini menjadi sorotan bagi masyarakat terutama pada kasus yang berkaitan dengan keuangan (Bagustianto \& Nurkholis, 2015).

Banyaknya kasus dari luar negeri hingga kasus yang ada di Indonesia sendiri tidak sedikit yang melibatkan auditor seperti kasus yang terjadi pada perusahaan penerbangan PT. Garuda Indonesia. Dalam kasus tersebut melibatkan auditor laporan keuangan, yakni Akuntan Publik (AP) Kasner Sirumapea Kantor Akuntan Publik (KAP) Tanubrata Sutanto Fahmi Bambang \& Rekan (Member of BDO Internasional) (Hartomo, 2019). Dalam kasus ini dijelaskan bahwa Garuda Indonesia memasukan keuntungan dari PT Mahata Aero Teknologi yang memiliki utang terkait pemasangan wifi kepada maskapai tersebut. Dari kasus tersebut dapat dikatakan bahwa auditor Garuda Indonesia tidak memiliki sifat independen dan profesional karena auditor Garuda Indoesia disini dapat dipengaruhi oleh manajemen dalam pembuatan laporan audit.

Dalam kasus lain yaitu Otoritas Jasa Keuangan (OJK) menetapkan sanksi denda kepada Direktur Utama PT Hanson Internasional Tbk (MYRX) sebesar Rp 5 miliar (CNN Indonesia, 2019). Hal tersebut berkaitan dengan manipulasi laporan keuangan perusahaan sejak tahun 2016 silam. Deputi Komisioner Pengawas Pasar Modal I mengungkapkan pelanggaran yang dilakukan perusahaan itu ialah terkait Standar Akuntansi Keuangan 44 tentang Akuntansi Aktivitas Real Estat (PSAK 44) dalam penjualan Kavling Siap Bangun (Kasiba) senilai Rp 732 miliar. Atas tindakan itu, OJK menyatakan Dirut PT Hanson Internasional telah melanggar Pasal 107 Undang-Undang Nomor 8 Tahun 1995 tentang Pasar Modal (UUPM).

Adanya kasus-kasus kecurangan yang terjadi, maka dibutuhkan kebijakan untuk mencegah terjadinya kasus kecurangan salah satunya dengan menerapkan kebijakan whistleblowing. Menurut Near dan Miceli (1985) whistleblowing adalah suatu tindakan sukarela yang dilakukan secara sengaja untuk mengungkapkan kesalahan dan/atau kecurangan dalam suatu organisasi oleh anggota atau mantan anggota dari suatu organisasi kepada orang atau organisasi yang mungkin saja melakukan kecurangan. Sistem whistleblowing di Indonesia sudah diterapkan di perusahaan sektor publik maupun swasta seperti Telkom, Pertamina, Bank Negara Indonesia (BRI), Astra Group, Direktorat Jenderal Pajak, dan lain-lain (Wijayanti \& Yandra, 2020).

Pihak yang melaporkan kecurangan dapat berasal dari internal perusahaan maupun eksternal perusahaan seperti auditor, pelanggan, bahkan masyarakat (Iqbal dkk., 2019). Namun untuk mengungkap adanya kecurangan atau menjadi whistleblower bukan sesuatu yang mudah. Penelitian sebelumnya telah menemukan beberapa faktor yang berpengaruh terhadap niat melakukan whistleblowing antara lain tingkat keseriusan pelanggaran, reporting channelatau saluran pelaporan, dan retaliasi atau tindakan balas dendam.

Tingkat keseriusan pelanggaran yang tinggi memungkinkan anggota organisasi untuk melakukan whistleblowing (Miceli \& Near, 1985). Penelitian Andon dkk. (2016) menyatakan bahwa persepsi tentang keseriusan pelanggaran secara signifikan dan positif berpengaruh pada niat akuntan untuk melakukan whistleblowing kepada pihak otoritas eksternal yang berwenang. Hal ini serupa dengan penelitian Cassematis \& Wortley (2013), Winardi (2013), Nawawi dan Salin (2018), Dianingsih dan Pratolo (2018), Latan dkk. (2019), Zamzami dkk. (2020) yang menyatakan bahwa tingkat keseriusan pelanggaran berpengaruh positif terhadap niat melakukan whistleblowing. Namun berbeda dengan penelitian yang dilakukan oleh Aliyah (2015), Hanif dan Odiatma (2017), dan Sartika dan Mulyani (2020) yang mengatakan bahwa tingkat keseriusan pelanggaran tidak berpengaruh terhadap niat melakukan whistleblowing, yang mana dari pernyataan tersebut dapat diartikan bahwa whistleblower tidak lagi menilai pelanggaran dari tingkat keseriusannya, namun sepanjang pelanggaran tersebut memang terjadi dan merugikan organisasi maka hal tersebut cukup menjadi dasar untuk melakukan whistleblowing. 
Reporting channel atau saluran pelaporan merupakan jalur bagi pelapor untuk melaporkan adanya kecurangan. Menurut Park dkk. (2007) reporting channel dibagi kebeberapa tipe yaitu formal dan nonformal, anonim dan non-anonim, internal dan eksternal. Menurut penelitian sebelumnya yang dilakukan oleh Putri (2016) mengatakan bahwa saluran pelaporan anonim dalam model struktural lebih efektif daripada saluran pelaporan non-anonim. Selain itu pada penelitian sebelumnya yang dilakukan oleh Johansson dan Carey (2015), Kaplan dkk. (2012), Utami dkk. (2020), Harahap dkk. (2020), dan Jenkel dan Haen (2012) mengatakan bahwa niat seseorang melakukan whistleblowing akan meningkat ketika melaporkan melalui anonymous reporting channel daripada non-anonymous reporting channel. Berbeda dalam penelitian oleh Pope dan Lee (2013) serta Assari dan Dwita (2020) yang mengatakan bahwa ketersediaan anonymous reporting channel tidak berpengaruh terhadap niat seseorang dalam melakukan whistleblowing.

Adanya retaliasi juga menjadi pengaruh niat seseorang dalam melakukan whistleblowing: Retaliasi atau tindakan balas dendam adalah suatu perilaku yang ditujukan untuk mengembalikan tindakan yang pernah dilakukan (Nugraha, 2017). Dalam penelitian yang telah dilakukan sebelumnya seperti penelitian oleh Liyanarachchi dan Newdick (2009), Manafe (2015), MesmerMagnus dan Viswesvaran (2005), Yang dan Xu (2020), dan Dhamija dan Rai (2017) memberikan hasil bahwa dengan adanya retaliasi yang tinggi mempengaruhi niat seseorang untuk melakukan whistleblowing: Berbeda dengan penelitian yang dilakukan oleh Effendi dan Nuraini (2019) dan Della dkk. (2020) yang mengatakan bahwa retaliasi tidak berpengaruh pada niat seseorang untuk melakukan whistleblowing.

Perbedaan penelitian ini dengan penelitian sebelumnya yaitu pada penelitian ini mengganti variabel personal cost dengan variabel independen lainnya yaitu retaliasi. Personal cost merupakan pandangan pegawai terhadap risiko pembalasan/balas dendam atau sanksi dari anggota organisasi sedangkan retaliasi atau tindakan balas dendam merupakan perilaku yang ditujukan untuk mengembalikan atau membalas tindakan yang pernah dilakukan seseorang (Nugraha, 2017). Alasan penelitian ini mengganti personal cost dengan retaliasi dikarenakan terdapat perbedaan hasil pada penelitian terdahulu yang membahas terkait variabel retaliasi. Dalam penelitian Kenny dkk. (2019) mengatakan bahwa adanya retaliasi yang tinggi dapat mengganggu kesehatan mental pelapor. Oleh sebab itu retaliasi menjadi pertimbangan tersendiri bagi seseorang untuk mengungkap kecurangan. Adanya penelitian tersebut menjadi salah satu pertimbangan peneliti untuk meneliti lebih lanjut terkait pengaruh retaliasi terhadap niat melakukan whistleblowing:

Perbedaan kedua antara penelitian ini dengan penelitian sebelumnya adalah mengganti variabel financial reward menjadi variabel tingkat keseriusan pelanggaran dikarenakan adanya pelanggaran yang serius dapat berdampak pada kerugian perusahaan yang mana dampak tersebut menjadi pertimbangan bagi pegawai di suatu perusahaan untuk melakukan whistleblowing. Penelitian ini menggunakan mahasiswa Program Studi Akuntansi Fakultas Ekonomi dan Bisnis Universitas Muhammadiyah Yogyakarta (FEB UMY) sebagai sampel penelitian. Menurut Poluakan dkk. (2017) mahasiswa memiliki tiga fungsi peran yaitu agent of change, social control, dan iron stock yang mana sebagai seorang agent perubahan mahasiswa dapat menjadi pelaku perubahan yang tentunya perubahan kearah positif. Kemudian peran social control terjadi ketika terdapat hal yang tidak baik di lingkungan masyarakat dan hendaknya mahasiswa memiliki jiwa kepedulian sosial dengan memberikan pemikiran kritis dan cemerlang, melakukan diskusi, atau bantuan moril dan materil kepada masyarakat. Sedangkan peran iron stock merupakan peran mahasiswa sebagai penerus bangsa yang memiliki kemampuan, keterampilan, dan akhlak mulia untuk menjadi seorang pemimpin yang baik. Oleh sebab itu selain alasan yang telah disebutkan sebelumnya, penelitian ini menggunakan subjek penelitian mahasiswa akuntansi karena untuk menguji apakah mahasiswa akuntansi memiliki pemahaman yang relevan dengan pekerja ketika mereka dihadapkan pada situasi yang sama.

Selain penelitian sebelumnya yang menjadi acuan adanya penelitian ini, adanya kasus-kasus kecurangan yang telah dipaparkan sebelumnya memotivasi peneliti untuk meneliti terkait faktor yang memengaruhi niat melakukan whistleblowing dengan judul "Pengaruh Tingkat Keseriusan Pelanggaran, Reporting Channel, dan Retaliasi terhadap Niat Melakukan Whistleblowing”. Adanya penelitian ini diharapkan dapat memberikan manfaat yang baik bagi perusahaan dan organisasi 
lainnya baik sektor publik maupun swasta untuk meningkatkan sistem pengendalian internal yang ada di perusahaan misalnya dengan menerapkan kebijakan whistleblowing:

\section{TINJAUAN LITERATUR DAN PERUMUSAN HIPOTESIS}

\section{Prosocial Behavior Theory}

Brief dan Motowidlo (1986) mendeskripsikan prosocial behavior theory sebagai perilaku atau tindakan anggota suatu organisasi yang ditujukan kepada individu, kelompok, atau organisasi tempat mereka bekerja dengan tujuan untuk kesejahteraan individu, kelompok, maupun organisasi itu sendiri. Menurut Dozier dan Miceli (1985) whistleblowing dapat dipandang sebagai perilaku prososial yang dapat memberi manfaat bagi kepentingan umum atau kegiatan altruistik, sekaligus dapat dipandang sebagai kegiatan yang mengandung egoisme. Berdasarkan pengertian Prosocial Behavior Theory, penelitian ini menggunakan teori Prosocial Behavior Theory dikarenakan teori ini salah satu teori yang mendukung konsep whistleblowing dimana whistleblowing didefinisikan sebagai kegiatan yang dilakukan seseorang atau sekelompok orang untuk mengungkapkan adanya kecurangan yang terjadi dalam suatu instansi atau organisasi (Near \& Miceli, 1985). Pengungkapan yang dilakukan seseorang atas terjadinya kecurangan tersebut merupakan suatu upaya untuk mengungkapkan adanya tindakan yang tidak etis atau ilegal yang dapat merugikan banyak pihak, baik pihak internal maupun eksternal perusahaan.

\section{Theory of Planned Behavior}

Theory of Planned Behavior adalah teori psikologi yang dikemukakan oleh Ajzen (1991) yang berusaha menjelaskan hubungan antara sikap dengan perilaku. Dalam teori ini kecenderungan terjadinya perilaku dapat diidentifikasi dengan minat. Menurut Ajzen (1991) minat dianggap sebagai faktor yang memengaruhi sebuah perilaku, yang ditunjukkan dengan seberapa keras usaha yang direncanakan seseorang untuk mencoba melakukan perilaku tersebut. Theory of Planned Behavior membuktikan bahwa minat menjadi suatu hal yang dapat memprediksi perilaku aktual dan sekaligus menjadi proxy yang menghubungkan antara sikap dan perilaku aktual (Sutrisni \& Coryanata, 2018). Minat terhadap perilaku dapat diartikan sebagai petunjuk atau tanda-tanda kesiapan seseorang untuk menunjukkan suatu perilaku (Lestari \& Yaya, 2017).

Secara ringkas, teori ini menjelaskan bahwa semakin besar keterlibatan seseorang dalam suatu perilaku maka akan semakin besar pula kinerja atau usaha yang dilakukan. Artinya, semakin besar komitmen seseorang dalam suatu organisasi maka akan semakin besar pula kinerja seseorang tersebut dalam organisasinya dan dalam pekerjaannya mereka akan berjalan sesuai dengan visi misi perusahaan atau organisasi. Sehingga ketika mereka menemukan suatu tindakan yang curang dan dapat merugikan perusahaan, maka mereka akan berusaha untuk mengungkap kecurangan tersebut. Oleh sebab itu penelitian ini menggunakan Theory of Planned Behavior dikarenakan dalam teori ini dapat menjelaskan sikap individu dalam melakukan suatu tindakan, sehingga teori ini berhubungan dengan penelitian yang sedang dilakukan.

\section{Whistleblowing}

Whistleblowing didefinisikan sebagai kegiatan yang dilakukan seseorang atau sekelompok orang untuk mengungkapkan adanya kecurangan yang terjadi dalam suatu instansi atau organisasi (Near \& Miceli, 1985). Whistleblowing adalah tindakan seorang karyawan atau mantan karyawan untuk mengungkap perilaku yang diyakini sebagai perilaku tidak etis atau ilegal kepada manajemen yang lebih tinggi atau kepada pihak eksternal yang memiliki wewenang (Bouville, 2007).

\section{Tingkat Keseriusan Pelanggaran}

Menurut Lestari dan Yaya (2017) keseriusan pelanggaran dapat didefinisikan sebagai akibat yang mungkin ditimbulkan dari adanya pelanggaran, baik secara finansial maupun non finansial. Tingkat keseriusan pelanggaran yang tinggi memungkinkan anggota organisasi untuk melakukan 
whistleblowing (Miceli \& Near, 1985). Adanya pelanggaran yang serius akan memberikan dampak kerugian yang besar pada organisasi (Winardi, 2013).

\section{Reporting Channel}

Reporting channelatau saluran pengungkapan merupakan jalur untuk menyampaikan adanya kecurangan oleh whistleblower. Saluran pelaporan ini telah diatur dalam Sarbanes-Oxley Act 2002, Section 301 dan 806 yang dirancang khusus untuk mendukung whistleblowing dan melindungi whistleblower dari adanya ancaman retaliasi (Putri, 2016). Dalam section 301 dan 806 ini meminta komite audit dari direksi perusahaan yang telah go public untuk memasang saluran pelaporan anonim. Menurut Park dkk. (2008), reporting channel dibagi kebeberapa tipe yaitu formal dan nonformal, anonim dan non-anonim, internal dan eksternal. Saluran pelaporan secara anonim atau anonymous reporting channel merupakan pelaporan kecurangan oleh karyawan atau pekerja dengan tidak menyebutkan identitas dari pelapor, sedangkan non-anonymous reporting channel (saluran pelaporan non-anonim) adalah pelaporan kecurangan oleh karyawan atau pekerja dengan formulir yang menyebutkan identitas pelapor.

\section{Retaliasi}

Retaliasi atau tindakan balas dendam adalah suatu perilaku yang ditujukan untuk mengembalikan tindakan yang pernah dilakukan (Nugraha, 2017). Bentuk dari retaliasi atau tindakan balas dendam dapat bermacam-macam. Menurut Mesmer-Magnus dan Viswesvaran (2005) bentuk retaliasi atau tindakan balas dendam dapat terjadi dalam berbagai bentuk seperti paksaan kepada pelapor untuk menarik tuduhan atas kecurangan yang telah dilakukan oleh pelaku. Tindakan balas dendam lainnya dapat berupa isolasi pelapor, pencemaran nama baik, potong gaji, pemecatan kerja, dan bentuk diskriminasi lainnya. Menurut Near dan Miceli (2008) retaliasi didefinisikan sebagai tindakan yang tidak diinginkan, yang diambil oleh pelaku terhadap pelapor.

\section{Retaliasi rendah dan retaliasi tinggi pada kondisi tingkat keseriusan pelanggaran rendah dan anonymous reporting channel terhadap niat melakukan whistleblowing}

Retaliasi atau tindakan balas dendam adalah suatu perilaku yang ditujukan untuk mengembalikan tindakan yang pernah dilakukan (Nugraha, 2017). Menurut penelitian sebelumnya yang dilakukan oleh Liyanarachchi dan Newdick (2009), Manafe (2015), Mesmer-Magnus dan Viswesvaran (2005), Yang dan Xu (2020), dan Dhamija dan Rai (2017) memberikan hasil bahwa dengan adanya retaliasi yang tinggi mempengaruhi niat seseorang untuk melakukan whistleblowing karena seseorang akan cenderung merasa dirinya terancam karena adanya retaliasi.

Tingkat keseriusan pelanggaran yang tinggi memungkinkan anggota organisasi untuk melakukan whistleblowing (Miceli \& Near, 1985). Adanya pelanggaran yang serius akan memberikan dampak kerugian yang besar pada organisasi (Winardi, 2013b). Menurut penelitian sebelumnya yang dilakukan oleh Christy dan Utami (2020), Andon dkk. (2016), Cassematis dan Wortley (2013), Winardi (2013), Nawawi dan Salin (2018), Dianingsih dan Pratolo (2018), Latan dkk. (2019), dan Zamzami dkk. (2020) menyatakan bahwa tingkat keseriusan pelanggaran berpengaruh terhadap niat melakukan whistleblowing.

Reporting channel atau saluran pelaporan whistleblowing telah diatur dalam Sarbanes-Oxley Act 2002, Section 301 dan 806 yang dirancang khusus untuk mendukung whistleblowing dan melindungi whistleblower dari adanya ancaman retaliasi. Dari hasil penelitian terdahulu yang membahas topik reporting channel adalah Johansson dan Carey (2015), Putri (2016), Kaplan dkk. (2012), Utami dkk. (2020), Harahap dkk. (2020), dan Jenkel dan Haen (2012) menyatakan bahwa melalui anonymous reporting channel dapat meningkatkan niat untuk melakukan whistleblowing.

Konsep whistleblowing sejalan dengan Theory of Planned Behaviour (TPB) yang menjelaskan hubungan antara sikap terhadap perilaku dimana teori ini menjelaskan bahwa semakin besar keterlibatan seseorang dalam suatu perilaku maka akan semakin besar pula kinerja atau usaha yang dilakukan. Artinya, semakin besar komitmen seseorang dalam suatu organisasi maka akan semakin besar pula kinerja seseorang tersebut dalam organisasinya dan dalam pekerjaannya mereka akan berjalan sesuai dengan visi misi perusahaan atau organisasi. Sehingga ketika mereka menemukan 
suatu kecurangan maka mereka akan berusaha untuk mengungkap kecurangan tersebut. Selain itu konsep whistleblowing sejalan pula dengan Prosocial Behavior Theory yang menjelaskan bahwa tindakan yang dilakukan oleh seseorang dalam suatu organisasi tidak hanya bertujuan untuk kepentingan pribadi, namun juga untuk kepentingan seluruh bagian yang ada di dalam organisasi.

Individu pada kondisi retaliasi rendah, tingkat keseriusan pelanggaran rendah, dan terdapat anonymous reporting channel akan meningkatkan niat seseorang untuk melakukan whistleblowing dibandingkan pada kondisi retaliasi tinggi, tingkat keseriusan pelanggaran rendah, dan terdapat anonymous reporting channel. Hal tersebut dikarenakan rasa aman bagi whistleblower untuk mengungkap kecurangan lebih tinggi pada kondisi retaliasi rendah dibandingkan pada kondisi retaliasi tinggi, serta didukung adanya anonymous reporting channel yaitu saluran pelaporan tanpa menunjukkan identitas pelapor. Berdasarkan uraian diatas maka diperoleh hipotesis 1 sebagai berikut:

$H_{i}$ : Pada kondisi tingkat keseriusan pelanggaran rendah, niat melakukan whistleblowing akan lebih tinggi bila anonymous reporting channel, dan retaliasi rendah dibandingkan dengan anonymous reporting channel dan retaliasi tinggi.

Retaliasi rendah dan retaliasi tinggi pada kondisi tingkat keseriusan pelanggaran rendah dan nonanonymous reporting channel terhadap niat melakukan whistleblowing

Menurut Nugraha (2017) retaliasi atau tindakan balas dendam adalah suatu perilaku yang ditujukan untuk mengembalikan tindakan yang pernah dilakukan. Tindakan balas dendam dapat berupa isolasi pelapor, pencemaran nama baik, potong gaji, pemutusan kontrak kerja, dan bentuk diskriminasi lainnya. Menurut penelitian sebelumnya yang dilakukan oleh Liyanarachchi dan Newdick (2009), Manafe (2015), Mesmer-Magnus dan Viswesvaran (2005), Yang dan Xu (2020), dan Dhamija dan Rai (2017) memberikan hasil bahwa dengan adanya retaliasi yang tinggi mempengaruhi niat seseorang untuk melakukan whistleblowing karena orang akan cenderung merasa dirinya terancam karena adanya retaliasi. Namun apabila tingkat retaliasi rendah maka akan meningkatkan atau mendorong seseorang untuk mengungkap adanya kecurangan.

Menurut Miceli dan Near (1985) tingkat keseriusan pelanggaran yang tinggi memungkinkan anggota organisasi untuk melakukan whistleblowing. Adanya pelanggaran yang serius akan memberikan dampak kerugian yang besar pada organisasi (Winardi, 2013). Menurut penelitian sebelumnya yang dilakukan oleh Christy dan Utami (2020), Andon dkk. (2016), Cassematis dan Wortley (2013), Winardi (2013), Aliyah (2015), Nawawi dan Salin (2018), Dianingsih dan Pratolo (2018), Latan dkk. (2019), dan Zamzami dkk. (2020) menyatakan bahwa tingkat keseriusan pelanggaran berpengaruh terhadap niat melakukan whistleblowing. Semakin tinggi keseriusan pelanggaran tersebut maka semakin tinggi pula kemungkinan seseorang atau anggota organisasi untuk melakukan whistleblowing.

Reporting channel atau saluran pelaporan whistleblowing telah diatur dalam Sarbanes-Oxley Act 2002, Section 301 dan 806 yang dirancang khusus untuk mendukung whistleblowing dan melindungi whistleblower dari adanya ancaman retaliasi. Dalam section 301 dan 806 ini meminta komite audit dari direksi perusahaan yang telah go public untuk memasang jalur pelaporan anonymous. Dari hasil penelitian terdahulu yang membahas topik reporting channeladalah Kaplan dkk. (2012), Jenkel dan Haen (2012), Putri (2016), Johansson dan Carey (2015), dan Harahap dkk. (2020) menyatakan bahwa melalui anonymous reporting channel dapat meningkatkan niat untuk melaporkan kecurangan.

Konsep whistleblowing sejalan dengan Theory of Planned Behaviour (TPB) yang menjelaskan hubungan antara sikap terhadap perilaku dimana teori ini menjelaskan bahwa semakin besar keterlibatan seseorang dalam suatu perilaku maka akan semakin besar pula kinerja atau usaha yang dilakukan. Artinya, semakin besar komitmen seseorang dalam suatu organisasi maka akan semakin besar pula kinerja seseorang tersebut dalam organisasinya dan dalam pekerjaannya mereka akan berjalan sesuai dengan visi misi perusahaan atau organisasi. Sehingga ketika mereka menemukan suatu kecurangan maka mereka akan berusaha untuk mengungkap kecurangan tersebut. Selain itu konsep whistleblowing sejalan pula dengan Prosocial Behavior Theory yang menjelaskan bahwa 
tindakan yang dilakukan oleh seseorang dalam suatu organisasi tidak hanya bertujuan untuk kepentingan pribadi, namun juga untuk kepentingan seluruh bagian yang ada di dalam organisasi.

Pada kondisi retaliasi rendah, tingkat keseriusan pelanggaran rendah, dan terdapat nonanonymous reporting channel akan meningkatkan niat seseorang untuk melakukan whistleblowing dibandingkan pada kondisi retaliasi tinggi, tingkat keseriusan pelanggaran rendah, dan terdapat nonanonymous reporting channel. Niat mengungkap kecurangan lebih tinggi dikarenakan rendahnya retaliasi atau tindakan balasan dendam yang kemungkinan akan diterima oleh whistleblower.

Berdasarkan uraian diatas maka diperoleh hipotesis sebagai berikut:

$H_{2:}$ Pada kondisi tingkat keseriusan pelanggaran rendah, niat melakukan whistleblowing akan lebih tinggi bila non-anonymous reporting channel, dan retaliasi rendah dibandingkan dengan nonanonymous reporting channel dan retaliasi tinggi.

\section{Retaliasi rendah dan retaliasi tinggi pada kondisi tingkat keseriusan pelanggaran tinggi dan anonymous reporting channel terhadap niat melakukan whistleblowing}

Retaliasi atau tindakan balas dendam adalah suatu perilaku yang ditujukan untuk mengembalikan tindakan yang pernah dilakukan (Nugraha, 2017). Menurut penelitian sebelumnya yang dilakukan oleh Liyanarachchi dan Newdick (2009), Manafe (2015), Mesmer-Magnus dan Viswesvaran (2005), Yang dan Xu (2020), dan Dhamija dan Rai (2017) memberikan hasil bahwa dengan adanya retaliasi yang tinggi mempengaruhi niat seseorang untuk melakukan whistleblowing karena seseorang akan cenderung merasa dirinya terancam karena adanya retaliasi.

Tingkat keseriusan pelanggaran yang tinggi memungkinkan anggota organisasi untuk melakukan whistleblowing (Miceli \& Near, 1985). Adanya pelanggaran yang serius akan memberikan dampak kerugian yang besar pada organisasi (Winardi, 2013b). Menurut penelitian sebelumnya yang dilakukan oleh Christy dan Utami (2020), Andon dkk. (2016), Cassematis dan Wortley (2013), Winardi (2013), Nawawi dan Salin (2018), Dianingsih dan Pratolo (2018), Latan dkk. (2019), dan Zamzami dkk. (2020) menyatakan bahwa tingkat keseriusan pelanggaran berpengaruh terhadap niat melakukan whistleblowing.

Reporting channel atau saluran pelaporan whistleblowing telah diatur dalam Sarbanes-Oxley Act 2002, Section 301 dan 806 yang dirancang khusus untuk mendukung whistleblowing dan melindungi whistleblower dari adanya ancaman retaliasi. Dari hasil penelitian terdahulu yang membahas topik reporting channel adalah Johansson dan Carey (2015), Putri (2016), Kaplan dkk. (2012), Utami dkk. (2020), Harahap dkk. (2020), dan Jenkel dan Haen (2012) menyatakan bahwa melalui anonymous reporting channel dapat meningkatkan niat untuk melakukan whistleblowing.

Konsep whistleblowing sejalan dengan Theory of Planned Behaviour (TPB) yang menjelaskan hubungan antara sikap terhadap perilaku dimana teori ini menjelaskan bahwa semakin besar keterlibatan seseorang dalam suatu perilaku maka akan semakin besar pula kinerja atau usaha yang dilakukan. Artinya, semakin besar komitmen seseorang dalam suatu organisasi maka akan semakin besar pula kinerja seseorang tersebut dalam organisasinya dan dalam pekerjaannya mereka akan berjalan sesuai dengan visi misi perusahaan atau organisasi. Sehingga ketika mereka menemukan suatu kecurangan maka mereka akan berusaha untuk mengungkap kecurangan tersebut. Selain itu konsep whistleblowing sejalan pula dengan Prosocial Behavior Theory yang menjelaskan bahwa tindakan yang dilakukan oleh seseorang dalam suatu organisasi tidak hanya bertujuan untuk kepentingan pribadi, namun juga untuk kepentingan seluruh bagian yang ada di dalam organisasi.

Individu pada kondisi retaliasi rendah, tingkat keseriusan pelanggaran tinggi, dan terdapat anonymous reporting channel akan meningkatkan niat seseorang untuk melakukan whistleblowing dibandingkan pada kondisi retaliasi tinggi, tingkat keseriusan pelanggaran tinggi, dan terdapat anonymous reporting channel. Hal tersebut dikarenakan adanya retaliasi rendah dan anonymous reporting channel akan memberikan rasa aman bagi whistleblower dan besarnya dampak dari keseriusan pelanggaran yang tinggi terhadap organisasi akan meningkatkan niat seseorang untuk melakukan whistleblowing. Berdasarkan uraian diatas dan hasil pada penelitian yang telah 
dilakukan sebelumnya serta teori yang mendasari penelitian ini maka diperoleh hipotesis ketiga sebagai berikut:

$\boldsymbol{H}_{3}$ : Pada kondisi tingkat keseriusan pelanggaran tinggi, niat melakukan whistleblowing akan lebih tinggi bila anonymous reporting channel, dan retaliasi rendah dibandingkan dengan anonymous reporting channel dan retaliasi tinggi.

Retaliasi rendah dan retaliasi tinggi pada kondisi tingkat keseriusan pelanggaran tinggi dan nonanonymous reporting channel terhadap niat melakukan whistleblowing

Menurut Nugraha (2017) retaliasi atau tindakan balas dendam adalah suatu perilaku yang ditujukan untuk mengembalikan tindakan yang pernah dilakukan. Tindakan balas dendam dapat berupa isolasi pelapor, pencemaran nama baik, potong gaji, pemutusan kontrak kerja, dan bentuk diskriminasi lainnya. Menurut penelitian sebelumnya yang dilakukan oleh Liyanarachchi dan Newdick (2009), Manafe (2015), Mesmer-Magnus dan Viswesvaran (2005), Yang dan Xu (2020), dan Dhamija dan Rai (2017) memberikan hasil bahwa dengan adanya retaliasi yang tinggi mempengaruhi niat seseorang untuk melakukan whistleblowing karena orang akan cenderung merasa dirinya terancam karena adanya retaliasi. Namun apabila tingkat retaliasi rendah maka akan meningkatkan atau mendorong seseorang untuk mengungkap adanya kecurangan.

Menurut Miceli dan Near (1985) tingkat keseriusan pelanggaran yang tinggi memungkinkan anggota organisasi untuk melakukan whistleblowing. Adanya pelanggaran yang serius akan memberikan dampak kerugian yang besar pada organisasi (Winardi, 2013). Menurut penelitian sebelumnya yang dilakukan oleh Christy dan Utami (2020), Andon dkk. (2016), Cassematis dan Wortley (2013), Winardi (2013), Aliyah $d k k$ (2015), Nawawi dan Salin (2018), Dianingsih dan Pratolo (2018), Latan dkk. (2019), dan Zamzami dkk. (2020) menyatakan bahwa tingkat keseriusan pelanggaran berpengaruh terhadap niat melakukan whistleblowing. Semakin tinggi keseriusan pelanggaran tersebut maka semakin tinggi pula kemungkinan seseorang atau anggota organisasi untuk melakukan whistleblowing.

Reporting channel atau saluran pelaporan whistleblowing telah diatur dalam Sarbanes-Oxley Act 2002, Section 301 dan 806 yang dirancang khusus untuk mendukung whistleblowing dan melindungi whistleblower dari adanya ancaman retaliasi. Dalam section 301 dan 806 ini meminta komite audit dari direksi perusahaan yang telah go public untuk memasang jalur pelaporan anonymous. Dari hasil penelitian terdahulu yang membahas topik reporting channeladalah Kaplan dkk. (2012), Jenkel dan Haen (2012), Putri (2016), Johansson dan Carey (2015), dan Harahap dkk. (2020) menyatakan bahwa melalui anonymous reporting channel dapat meningkatkan niat untuk melaporkan kecurangan.

Konsep whistleblowing sejalan dengan Theory of Planned Behaviour (TPB) yang menjelaskan hubungan antara sikap terhadap perilaku dimana teori ini menjelaskan bahwa semakin besar keterlibatan seseorang dalam suatu perilaku maka akan semakin besar pula kinerja atau usaha yang dilakukan. Artinya, semakin besar komitmen seseorang dalam suatu organisasi maka akan semakin besar pula kinerja seseorang tersebut dalam organisasinya dan dalam pekerjaannya mereka akan berjalan sesuai dengan visi misi perusahaan atau organisasi. Sehingga ketika mereka menemukan suatu kecurangan maka mereka akan berusaha untuk mengungkap kecurangan tersebut. Selain itu konsep whistleblowing sejalan pula dengan Prosocial Behavior Theory yang menjelaskan bahwa tindakan yang dilakukan oleh seseorang dalam suatu organisasi tidak hanya bertujuan untuk kepentingan pribadi, namun juga untuk kepentingan seluruh bagian yang ada di dalam organisasi.

Individu pada kondisi retaliasi rendah, tingkat keseriusan pelanggaran rendah, dan terdapat non-anonymous reporting channel akan meningkatkan niat seseorang untuk melakukan whistleblowing dibandingkan pada kondisi retaliasi tinggi, tingkat keseriusan pelanggaran rendah, dan terdapat non-anonymous reporting channel. Hal tersebut dikarenakan whistleblower akan merasa lebih aman ketika tingkat balas dendam yang didapat lebih rendah. Selain itu adanya dampak yang tinggi terhadap organisasi akibat tingkat keseriusan pelanggaran yang tinggi, mendorong niat seseorang untuk mengungkap kecurangan. Berdasarkan uraian diatas dan hasil 
pada penelitian yang telah dilakukan sebelumnya serta teori yang mendasari penelitian in maka diperoleh hipotesis keempat sebagai berikut:

$\boldsymbol{H}_{4:}$ Pada kondisi tingkat keseriusan pelanggaran tinggi, niat melakukan whistleblowing akan lebih tinggi bila non-anonymous reporting channel, dan retaliasi rendah dibandingkan dengan nonanonymous reporting channel dan retaliasi tinggi.

\section{METODE PENELITIAN}

\section{Subyek Penelitian}

Penelitian ini menggunakan subjek penelitian yaitu mahasiswa Akuntansi Fakultas Ekonomi dan Bisnis Universitas Muhammadiyah Yogyakarta (FEB UMY) minimal semester lima atau angkatan 2018.

\section{Jenis Data}

Jenis data dalam penelitian ini menggunakan data primer. Data primer dalam penelitian ini diperoleh menggunakan metode eksperimen. Jenis penelitian yang digunakan adalah eksperimen semu (quasi-experimental design).

\section{Populasi dan Teknik Pengambilan Sampel}

Populasi dalam penelitian ini adalah mahasiswa Program Studi Akuntansi Fakultas Ekonomi dan Bisnis Universitas Muhammadiyah Yogyakarta minimal semester 5 atau minimal angkatan 2018. Mahasiswa yang menjadi subyek penelitian adalah mahasiswa yang sudah atau sedang mengambil mata kuliah yang telah disyaratkan dalam penelitian ini. Teknik pengambilan sampel dalam penelitian ini menggunakan metode purposive sampling: Sampel dalam penelitian ini adalah mahasiswa Akuntansi yang telah atau sedang mengambil mata kuliah Pengauditan, Pengauditan Manajemen Internal, dan Etika Profesi.

\section{Teknik Pengumpulan Data}

Teknik pengumpulan data pada penelitian ini menggunakan metode eksperimen. Sebelum melakukan eksperimen, dilakukan pengujian pilot test untuk memastikan bahwa partisipan dapat memahami kasus yang diberikan. Eksperimen pada penelitian ini dirancang dalam 4 tahap penelitian sebagai berikut:

1. Tahap Pengisian Data Demografis Partisipan

Tahap pertama, partisipan diminta untuk mengisi data diri yaitu nama, jenis kelamin, umur, program studi, semester saat ini.

2. Tahap Eksperimen

Tahap kedua yaitu tahap eksperimen. Partisipan dibagi ke dalam 8 grup dan setiap grup akan diberi kasus dengan kondisi yang berbeda. Kasus terdiri dari kasus 1, 2, 3, 4, 5, 6, 7, dan 8.

3. Tahap Pengambilan Keputusan

Tahap ketiga yaitu tahap pengambilan keputusan yang mana dalam tahap ini partisipan diminta untuk menentukan preferensi atas pilihan kemungkinan untuk melakukan whistleblowing, apakah partisipan sebagai akuntan senior akan melakukan whistleblowing atau tidak berdasarkan kondisi yang telah diberikan dalam kasus.

4. Tahap Manipulation Check

Pada tahap ini, partisipan diminta untuk mengisi/menjawab soal manipulation check yang telah disediakan.

\section{Definisi Operasional Variabel Penelitian}

\section{Variabel Dependen}

Pada penelitian ini variable dependen yang digunakan adalah niat melakukan whistleblowing yang diukur menggunakan skala 9 poin dimana nilai 1 menunjukkan tidak berniat melakukan 
whistleblowing dan angka 9 menunjukkan niat yang tinggi untuk melakukan whistleblowing. Instrumen yang digunakan dalam penelitian ini dikembangkan sendiri oleh peneliti dengan mengambil referensi dari Seifert dkk. (2010) dan Utami dkk. (2020).

\section{Variabel Independen}

Variabel independen pada penelitian ini adalah tingkat keseriusan pelanggaran, reporting channel, dan retaliasi.

a. Instrumen penelitian terkait variabel tingkat keseriusan pelanggaran dikembangkan sendiri oleh oleh peneliti dengan mengambil referensi dari penelitian Robinson dkk. (2012) dan Zhuang (2003). Kategori tingkat keseriusan pelanggaran dalam penelitian ini terdiri dari 2 (dua) kategori yaitu tingkat keseriusan pelanggaran rendah dan tingkat keseriusan pelanggaran tinggi. Manipulasi tingkat keseriusan pelanggaran rendah dalam kasus diinformasikan bahwa pelanggaran yang terjadi masih dapat ditoleransi dan tidak menimbulkan kerugian yang besar bagi perusahaan. Manipulasi tingkat keseriusan pelanggaran tinggi dalam kasus diinformasikan bahwa pelanggaran yang terjadi sudah tidak dapat ditoleransi lagi dan menimbulkan dampak kerugian yang besar bagi perusahaan.

b. Instrumen penelitian terkait variabel reporting channel dikembangkan oleh peneliti dengan mengambil referensi dari penelitian Harahap dkk. (2020), Kaplan dkk. (2009), Ayers dan Kaplan (2005), dan Seifert dkk. (2010). Dalam penelitian ini reporting channel dibagi ke dalam dua kategori yaitu anonymous reporting channel dan non-anonymous reporting channel. Anonymous reporting channel atau saluran pelaporan anonim merupakan pelaporan kecurangan dengan menyembunyikan identitas dari pelapor sedangkan nonanonymous reporting channel atau saluran pelaporan non-anonim merupakan pelaporan dengan mengungkapkan identitas dari pelapor. Manipulasi anonymous reporting channel dalam kasus diinformasikan dengan mencantumkan pernyataan terkait adanya saluran pelaporan secara anonim atau dengan menyembunyikan identitas pelapor. Manipulasi nonanonymous reporting channel dalam kasus diinformasi dengan mencantumkan pernyataan terkait adanya saluran pelaporan secara non-anonim atau dengan mengungkap identitas pelapor.

c. Instrumen penelitian terkait variabel retaliasi dikembangkan sendiri oleh oleh peneliti dengan mengambil referensi dari penelitian Guthrie dan Taylor (2017) dan Theotama (2020). Dalam penelitian ini retaliasi terdiri dari 2 (dua) kategori retaliasi yaitu retaliasi rendah dan retaliasi tinggi. Tingkat retaliasi rendah yaitu tingkat balas dendam yang didapat oleh whistleblower masih dalam batas rendah. Sedangkan tingkat retaliasi tinggi yaitu tingkat balas dendam yang didapat oleh whistleblower sudah dalam batas yang tinggi. Dalam penelitian ini manipulasi retaliasi rendah dalam kasus diinformasikan bahwa individu yang mengungkap adanya kecurangan akan mendapat retaliasi atau tindakan balas dendam yang rendah berupa pemotongan gaji dan adanya tindakan disipliner bagi pelaku retaliasi. Sedangkan manipulasi retaliasi tinggi dalam kasus diinformasikan bahwa individu yang mengungkap adanya kecurangan akan mendapat retaliasi atau tindakan balas dendam yang tinggi berupa pemecatan kerja dan pencemaran nama baik serta tidak adanya tindakan disipliner bagi pelaku retaliasi.

\section{Desain Penelitian}

Dalam penelitian ini masing-masing variabel independen memiliki 2 (dua) faktor. Faktor dalam setiap variabel yaitu tingkat keseriusan pelanggan (rendah dan tinggi), reporting channel (anonymous reporting channel dan non-anonymous reporting channeh), dan retaliasi (rendah dan tinggi). Sehingga penelitian ini menggunakan desain eksperimen faktorial 2x2x2 between subject. Desain dalam penelitian ini ditunjukkan pada Tabel dibawah ini: 
Tabel 1 Desain Faktorial 2x2x2 Between Subject

\begin{tabular}{|l|c|l|l|l|}
\hline \multirow{4}{*}{ Perlakuan } & \multicolumn{2}{|c|}{$\begin{array}{c}\text { Tingkat Keseriusan Pelanggaran } \\
\text { (Rendah) }\end{array}$} & $\begin{array}{l}\text { Tingkat Keseriusan Pelanggaran } \\
\text { (Tingi) }\end{array}$ \\
\cline { 2 - 6 } & $\begin{array}{l}\text { Anonymous } \\
\text { Reporting } \\
\text { Channel }\end{array}$ & $\begin{array}{l}\text { Non- } \\
\text { Anonymous } \\
\text { Reporting } \\
\text { Channel }\end{array}$ & $\begin{array}{l}\text { Anonymous } \\
\text { Reporting } \\
\text { Channel }\end{array}$ & $\begin{array}{l}\text { Non- } \\
\text { anonymous } \\
\text { Reporting } \\
\text { Channel }\end{array}$ \\
\hline Retaliasi rendah & Kasus 1 & Kasus 3 & Kasus 5 & Kasus 7 \\
\hline Retaliasi tinggi & Kasus 2 & Kasus 4 & Kasus 6 & Kasus 8 \\
\hline
\end{tabular}

\section{HASIL DAN PEMBAHASAN}

\section{Pilot Test}

Hasil pilot test yang telah dilakukan kepada 16 mahasiswa Program Studi Akuntansi Fakultas Ekonomi dan Bisnis Universitas Muhammadiyah Yogyakarta menunjukkan 16 peserta lolos menjawab pertanyaan manipulation check dengan 5 peserta berhasil menjawab benar seluruh pertanyaan dan 11 peserta berhasil menjawab benar empat dari lima pertanyaan.

\section{Uji Normalitas}

Berdasarkan hasil uji normalitas, dapat dilihat bahwa nilai Asymp. Sig. (2 tailed) 0,200 lebih besar dari signifikansi 0,05 . Hal tersebut menggambarkan bahwa residual data menyebar secara normal atau berdistribusi normal.

Tabel 2 Hasil Uji Normalitas

Variabel Dependen: Niat melakukan whistleblowing

\begin{tabular}{lc}
\hline & Unstandardized \\
Residual \\
\hline N & 115 \\
Mean & 0,0000000 \\
Std. Deviation & 1,42857154 \\
Asymp. Sig. (2-tailed) & 0,200 \\
\hline
\end{tabular}

\section{Uji Homogenitas}

Hasil uji Levene's test of homogeneity of variance menunjukkan signifikansi 0,720 lebih besar dari 0,05 yang berarti asumsi homogenitas diterima bahwa semua variansi populasi sama.

Tabel 3 Hasil Uji Homogenitas

Variabel Dependen: Niat melakukan whistleblowing

\begin{tabular}{cccc}
\hline $\mathbf{F}$ & df1 & df2 & Sig. \\
\hline 0,642 & 7 & 107 & 0,720 \\
\hline
\end{tabular}

\section{Uji Hipotesis}

Pengujian hipotesis dalam penelitian ini menggunakan alat bantu analysys of variance (ANOVA).

\section{A. Hasil dan interpretasi main effect}

Pada Tabel 4 menunjukkan hasil uji main effect dan interaction effect pada setiap perlakuan yaitu tingkat keseriusan pelanggaran, reporting channel, dan retaliasi. Hasil uji between subject menunjukkan hasil berikut: 
1. Probabilitas tingkat keseriusan pelanggaran (Tabel 4) memiliki signifikansi 0,086 lebih besar dari 0,05. Dilihat dari rata-rata (Tabel 6), tingkat keseriusan pelanggaran rendah dan tingkat keseriusan pelanggaran tinggi memiliki nilai yang berbeda yaitu tingkat keseriusan pelanggaran rendah 7,15 dan tingkat keseriusan pelanggaran tinggi 6,70. Hal ini menunjukkan bahwa niat individu melakukan whistleblowing berbeda pada kondisi tingkat keseriusan pelanggaran rendah dan tingkat keseriusan pelanggaran tinggi.

2. Probabilitas reporting channel (Tabel 4) memiliki nilai signifikansi 0,003 lebih kecil dari 0,05. Dilihat dari rata-rata (Tabel 6), adanya anonymous reporting channel berbeda dengan nonanonymous reporting channel. Rata-rata anonymous reporting channel senilai 7,32 dan rata-rata non-anonymous reporting channel senilai 6,53 . Hal ini menunjukkan bahwa terdapat pengaruh langsung variabel independen reporting channel terhadap niat individu melakukan whistleblowing dan niat individu melakukan whistleblowing berbeda pada kondisi anonymous reporting channel dengan non-anonymous reporting channel.

3. Probabilitas retaliasi (Tabel 4) memiliki nilai signifikansi 0,025 lebih kecil dari 0,05. Dilihat dari rata-rata (Tabel 6), adanya retaliasi rendah berbeda dengan retaliasi tinggi. Rata-rata retaliasi rendah senilai 7,22 dan rata-rata retaliasi tinggi senilai 6,63. Hal ini menunjukkan bahwa terdapat pengaruh langsung variabel independen retaliasi terhadap niat individu melakukan whistleblowing dan niat individu melakukan whistleblowing berbeda pada kondisi retaliasi rendah dengan retaliasi tinggi.

Tabel 4 Hasil Uji ANOVA Test of Between-Subjects Effect Variabel Dependen: Niat melakukan whistleblowing

\begin{tabular}{lcccc}
\multicolumn{1}{c}{ Source } & $\begin{array}{c}\text { Sum of } \\
\text { Squares }\end{array}$ & df & F & Sig. \\
\hline Corrected Model & 56,729 & 7 & 4,138 & 0,000 \\
Intercept & 5500,569 & 1 & 2808,466 & 0,000 \\
Keseriusan_Pelanggaran & 5,900 & 1 & 3,013 & 0,086 \\
Reporting_Channel & 17,975 & 1 & 9,178 & 0,003 \\
Retaliasi & 10,121 & 1 & 5,168 & 0,025 \\
KP * RC & 9,017 & 1 & 4,604 & 0,034 \\
KP $^{*}$ Retaliasi & 11,203 & 1 & 5,720 & 0,019 \\
RC $^{*}$ Retaliasi & 0,927 & 1 & 0,473 & 0,493 \\
KP $^{*}$ RC * Retaliasi & 2,283 & 1 & 1,166 & 0,283 \\
Total & 5776,000 & 115 & & \\
Corrected Total & 266,296 & 114 & & \\
\hline
\end{tabular}

B. Hasil dan interpretasi uji interaksi

Pada bagian ini menyajikan hasil uji interaksi dan interprtasinya antar variabel dalam desain eksperimen 2x2x2 between subject. Pada Tabel 5 menampilkan probabilitas perbandingan antar grup eksperimen sedangkan Tabel 6 menampilkan mean, standar deviasi, dan jumlah partisipan setiap grup.

Tabel 5 Hasil Uji ANOVA (Perbandingan)

Variabel Dependen: Niat melakukan whistleblowing

\begin{tabular}{cccc}
\hline Sumber & Mean Diff (I-J) & SE & Sig \\
\hline Grup 1 - Grup 2 & $-0,13$ & 0,443 & 1,000 \\
Grup 3 - Grup 4 & $-0,34$ & 0,467 & 1,000 \\
Grup 5 - Grup 6 & 1,54 & 0,450 & 0,034 \\
Grup 7 - Grup 8 & 0,76 & 0,450 & 0,829 \\
\hline
\end{tabular}


Tabel 6 Mean (Standar Deviasi) dan Jumlah Partisipan Setiap Grup

\begin{tabular}{|c|c|c|c|c|c|}
\hline & \multicolumn{2}{|c|}{$\begin{array}{c}\text { Tingkat Keseriusan Pelanggaran } \\
\text { (Rendah) }\end{array}$} & \multicolumn{2}{|c|}{$\begin{array}{c}\text { Tingkat Keseriusan Pelanggaran } \\
\text { (Tinggi) }\end{array}$} & \multirow[b]{2}{*}{$\begin{array}{l}\text { Rata-rata } \\
\text { Retaliasi }\end{array}$} \\
\hline & $\begin{array}{l}\text { Anonymous } \\
\text { Reporting } \\
\text { Channel }\end{array}$ & $\begin{array}{l}\text { Non- } \\
\text { Anonymous } \\
\text { Reporting } \\
\text { Channel }\end{array}$ & $\begin{array}{l}\text { Anonymous } \\
\text { Reporting } \\
\text { Channel }\end{array}$ & \begin{tabular}{|l|} 
Non- \\
anonymous \\
Reporting \\
Channel
\end{tabular} & \\
\hline $\begin{array}{l}\text { Retaliasi } \\
\text { rendah }\end{array}$ & $\begin{array}{c}\text { Kasus } 1 \\
7,20 \\
15\end{array}$ & $\begin{array}{c}\text { Kasus } 3 \\
7,07 \\
14\end{array}$ & $\begin{array}{c}\text { Kasus } 5 \\
8,21 \\
14\end{array}$ & $\begin{array}{c}\text { Kasus } 7 \\
6,40 \\
15\end{array}$ & 7,22 \\
\hline $\begin{array}{l}\text { Retaliasi } \\
\text { tinggi }\end{array}$ & $\begin{array}{c}\text { Kasus } 2 \\
7,33 \\
15\end{array}$ & $\begin{array}{c}\text { Kasus } 4 \\
7,00 \\
13\end{array}$ & $\begin{array}{c}\text { Kasus } 6 \\
6,53 \\
15\end{array}$ & $\begin{array}{c}\text { Kasus } 8 \\
5,64 \\
15\end{array}$ & 6,63 \\
\hline \multicolumn{2}{|c|}{$\begin{array}{c}\text { Rata-rata Tingkat Keseriusan } \\
\text { Pelanggaran Rendah } \\
\end{array}$} & 7,15 & \multicolumn{2}{|c|}{$\begin{array}{c}\text { Rata-rata Tingkat Keseriusan } \\
\text { Pelanggaran Tinggi }\end{array}$} & 6,70 \\
\hline \multicolumn{2}{|c|}{$\begin{array}{c}\text { Rata-rata Anonymous } \\
\text { Reporting Channel }\end{array}$} & 7,32 & \multicolumn{2}{|c|}{$\begin{array}{c}\text { Rata-rata Non-Anonymous } \\
\text { Reporting Channel }\end{array}$} & 6,53 \\
\hline
\end{tabular}

Hasil uji Post Hoc pada Tabel 5 serta mean, standar deviasi, dan jumlah partisipan setiap grup pada Tabel 6 menunjukkan bahwa:

1. Probabilitas (Tabel 5) antara grup 1 dan grup 2 memiliki nilai signifikansi 1,000 lebih besar dari 0,05. Jika dilihat dari rata-rata (Tabel 6) yaitu grup 1 senilai 7,20 dan grup 2 senilai 7,33. Hasil uji post hoc dan rata-rata tersebut menunjukkan tidak adanya perbedaan yang signifikan dari kedua grup.

2. Probabilitas (Tabel 5) antara grup 3 dan grup 4 memiliki nilai signifikansi 1,000 lebih besar dari 0,05. Jika dilihat dari rata-rata (Tabel 6) yaitu grup 3 senilai 7,07 dan grup 4 senilai 7,00. Hasil uji post hoc dan rata-rata tersebut menunjukkan tidak adanya perbedaan yang signifikan dari kedua grup.

3. Probabilitas (Tabel 5) antara grup 5 dan grup 6 memiliki nilai signifikansi 0,034 lebih kecil dari 0,05. Jika dilihat dari rata-rata (Tabel 6) yaitu grup 5 senilai 8,21 dan grup 6 senilai 6,53. Hasil uji post hoc dan rata-rata tersebut menunjukkan adanya perbedaan yang signifikan dari kedua grup.

4. Probabilitas (Tabel 5) antara grup 7 dan grup 8 memiliki nilai signifikansi 0,829 lebih besar dari 0,05. Jika dilihat dari rata-rata (Tabel 6) yaitu grup 7 senilai 6,40 dan grup 8 senilai 5,64. Hasil uji post hoc dan rata-rata tersebut menunjukkan tidak adanya perbedaan yang signifikan dari kedua grup.

\section{Tingkat Keseriusan Pelanggaran}

Tingkat keseriusan pelanggaran memiliki probabilitas 0,086 (Tabel 4) lebih besar dari signifikansi 0,05. Jika dilihat dari rata-rata grup (Tabel 6), adanya tingkat keseriusan pelanggaran rendah tinggi memiliki nilai masing-masing 7,15 dan 6,70. Hasil ini menunjukkan bahwa niat individu untuk melakukan whistleblowing sama-sama tinggi pada kondisi tingkat keseriusan pelanggaran rendah dan tinggi. Untuk melaporkan tindakan pelanggaran individu tidak menilai berdasarkan tingkat keseriusan pelanggarannya.

Hasil ini sejalan dengan penelitian oleh Aliyah $d k k$ (2015), Hanif dan Odiatma (2017), dan Sartika dan Mulyani (2020) yang mengatakan bahwa tingkat keseriusan pelanggaran tidak berpengaruh terhadap niat melakukan whistleblowing, yang mana dari pernyataan tersebut dapat diartikan bahwa whistleblower tidak lagi menilai pelanggaran dari seberapa tinggi tingkat keseriusan dari pelanggaran, namun sepanjang pelanggaran tersebut memang terjadi dan merugikan organisasi maka hal tersebut cukup menjadi dasar untuk melakukan whistleblowing.

\section{Reporting Channel}

Reporting channel memiliki probabilitas 0,003 (Tabel 4) lebih kecil dari signifikansi 0,05. Jika dilihat dari rata-rata grup (Tabel 6), adanya anonymous reporting channel dan non-anonymous 
reporting channel memiliki nilai masing-masing 7,32 dan 6,53. Hasil ini menunjukkan bahwa niat individu untuk melakukan whistleblowing berbeda pada kondisi anonymous reporting channel dengan kondisi non-anonymous reporting channel. Individu akan lebih terdorong untuk melaporkan suatu pelanggaran apabila terdapat anonymous reporting channel dimana identitas pelapor akan dirahasiakan dari seluruh anggota organisasi. Sehingga pelapor merasa lebih aman dan terlindungi dari ancaman balas dendam oleh pelaku pelanggaran. Sebaliknya, dalam saluran pelaporan non-anonim atau non-anonymous reporting channel individu cenderung tidak melaporkan tindakan pelanggaran dikarenakan dalam jenis saluran pelaporan ini identitas pelapor tidak dirahasiakan dan dapat diketahui seluruh anggota organisasi termasuk pelaku pelanggaran. Akibatnya, kekhawatiran pelapor terhadap ancaman balas dendam oleh pelaku pelanggaran semakin tinggi.

Hasil ini sejalan dengan penelitian Putri (2016) yang menyatakan bahwa saluran pelaporan anonim dalam model struktural lebih efektif daripada saluran pelaporan non-anonim. Hasil ini sejalan pula dengan penelitian yang dilakukan oleh Kaplan dkk. (2012), Johansson dan Carey (2015), Utami dkk. (2020), Harahap dkk. (2020) yang menyatakan bahwa niat seseorang melakukan whistleblowing akan meningkat ketika melaporkan melalui anonymous reporting channel daripada non-anonymous reporting channel.

\section{Retaliasi}

Retaliasi memiliki probabilitas 0,025 (Tabel 4) lebih kecil dari signifikansi 0,05. Jika dilihat dari rata-rata grup (Tabel 6), adanya retaliasi rendah dan retaliasi tinggi memiliki nilai masing-masing 7,22 dan 6,63. Hasil ini menunjukkan bahwa niat individu untuk melakukan whistleblowing berbeda pada kondisi retaliasi rendah dengan kondisi retaliasi tinggi. Individu akan lebih terdorong untuk melaporkan suatu pelanggaran apabila tingkat retaliasinya rendah dan sebaliknya apabila terdapat tingkat retaliasi tinggi individu cenderung tidak melakukan whistleblowing. Hal tersebut dikarenakan adanya tingkat retaliasi tinggi membuat individu merasa takut terhadap akibat dari tindakan tersebut. Selain itu, tidak adanya aturan atau sistem yang melindungi pelapor tindakan pelanggaran menyebabkan kekhawatiran pelapor terhadap ancaman retaliasi semakin tinggi.

Hasil ini sejalan dengan penelitian yang dilakukan oleh Liyanarachchi dan Newdick (2009), Manafe (2015), Mesmer-Magnus dan Viswesvaran (2005), Yang dan Xu (2020), dan Dhamija dan Rai (2017) yang menyatakan bahwa dengan adanya retaliasi yang tinggi mempengaruhi niat seseorang untuk melakukan whistleblowing karena seseorang akan cenderung merasa dirinya terancam karena adanya retaliasi yang tinggi. Namun apabila tingkat retaliasi rendah maka akan meningkatkan atau mendorong niat seseorang untuk mengungkap adanya kecurangan karena rendahnya kekhawatiran seseorang tersebut terhadap adanya retaliasi.

\section{Retaliasi rendah dan retaliasi tinggi pada kondisi tingkat keseriusan pelanggaran rendah, anonymous reporting channel}

Hipotesis $1\left(\mathrm{H}_{1}\right)$ dalam penelitian adalah membandingkan antara grup 1 dengan grup 2 manakah grup yang memiliki rata-rata lebih tinggi. Perlakuan pada grup 1 adalah terdapat tingkat keseriusan pelanggaran rendah, anonymous reporting channel, dan retaliasi rendah. Sedangkan perlakuan grup 2 adalah terdapat tingkat keseriusan rendah, anonymous reporting channel, dan retaliasi tinggi.

Probabilitas antara grup 1 dan 2 (Tabel 5) memiliki nilai 1,000 lebih besar dari signifikansi 0,05. Jika dilihat dari rata-rata (Tabel 6) masing-masing grup adalah 7,20 untuk grup 1 dan 7,33 untuk grup 2. Hasil tersebut menunjukkan tidak adanya perbedaan yang signifikan dari kedua grup yang berarti antara grup 1 dan grup 2 keduanya memiliki keefektifan yang sama dalam mendorong whistleblowing: Selain itu, dari hasil rata-rata menunjukkan bahwa grup 2 memiliki nilai yang lebih tinggi dibandingkan grup 1 yaitu 7,33>7,20 namun perbedaan tersebut tidak terlalu tinggi. Berdasarkan hasil ini maka dapat disimpulkan bahwa $\mathrm{H}_{1}$ ditolak, artinya bahwa tidak ada perbedaan yang signifikan dalam kondisi tingkat keseriusan pelanggaran rendah, anonymous reporting channel, dan retaliasi rendah dibandingkan dengan kondisi tingkat keseriusan pelanggaran rendah, anonymous reporting channel, dan retaliasi tinggi. 
Hasil uji hipotesis 1 ini menunjukkan seseorang akan tetap terdorong untuk melaporkan tindakan kecurangan kepada pihak berwenang walaupun dihadapkan pada kondisi terdapat retaliasi rendah maupun retaliasi tinggi, tingkat keseriusan pelanggaran rendah, dan anonymous reporting channel atau saluran pelaporan anonim. Adanya kondisi seperti pada uji hipotesis 1 , maka dapat diketahui bahwa tujuan seseorang melaporkan tindakan pelanggaran bukan untuk mencari keuntungan pribadi, namun bertujuan untuk kesejahteraan perusahaan dan seluruh bagian yang ada di dalam perusahaanHasil penelitian pada $\mathrm{H}_{1}$ ini sejalan dengan Prosocial Behavior Theory yang menjelaskan bahwa tindakan yang dilakukan oleh seseorang dalam suatu organisasi tidak hanya bertujuan untuk kepentingan pribadi, namun juga untuk kepentingan seluruh bagian yang ada dalam organisasi dan whistleblowing merupakan salah satu bentuk dari perilaku prososial (Brief \& Motowidlo, 1986). Hasil ini juga sejalan dengan Theory of Planned Behaviour (TPB) yang menjelaskan terjadinya perilaku dapat diidentifikasi dengan niat. Niat dianggap sebagai faktor yang memengaruhi sebuah perilaku (Ajzen, 1991).

\section{Retaliasi rendah dan retaliasi tinggi pada kondisi tingkat keseriusan pelanggaran rendah, non- anonymous reporting channel}

Hipotesis $2\left(\mathrm{H}_{2}\right)$ dalam penelitian adalah membandingkan antara grup 3 dengan grup 4 manakah grup yang memiliki rata-rata lebih tinggi. Perlakuan pada grup 3 adalah terdapat tingkat keseriusan pelanggaran rendah, non-anonymous reporting channel, dan retaliasi rendah. Sedangkan perlakuan pada grup 4 adalah terdapat tingkat keseriusan pelanggaran rendah, nonanonymous reporting channel, dan retaliasi tinggi.

Probabilitas antara grup 3 dan 4 (Tabel 4.7) memiliki nilai 1,000 lebih besar dari signifikansi 0,05. Jika dilihat dari rata-rata (Tabel 4.8) masing-masing grup adalah 7,07 untuk grup 3 dan 7,00 untuk grup 4. Hasil tersebut menunjukkan tidak adanya perbedaan yang signifikan dari kedua grup yang berarti antara grup 3 dan grup 4 keduanya memiliki keefektifan yang sama dalam mendorong whistleblowing: Selain itu, dari hasil rata-rata menunjukkan bahwa grup 3 memiliki nilai yang lebih tinggi dibandingkan grup 4 yaitu 7,07 > 7,00 namun perbedaan tersebut tidak terlalu tinggi. Berdasarkan hasil ini maka dapat disimpulkan bahwa $\mathrm{H}_{2}$ ditolak, artinya bahwa tidak ada perbedaan yang signifikan dalam kondisi tingkat keseriusan pelanggaran rendah, non-anonymous reporting channel, dan retaliasi rendah dibandingkan pada kondisi tingkat keseriusan pelanggaran rendah, non-anonymous reporting channel, dan retaliasi tinggi.

Hasil uji hipotesis 2 menunjukkan bahwa seseorang akan tetap terdorong untuk melaporkan tindakan kecurangan kepada pihak berwenang walaupun dihadapkan pada kondisi terdapat retaliasi rendah maupun retaliasi tinggi, tingkat keseriusan pelanggaran rendah, dan non-anonymous reporting channel. Adanya kondisi seperti pada uji hipotesis 2, maka dapat diketahui bahwa tujuan seseorang melaporkan tindakan pelanggaran bukan untuk mencari keuntungan pribadi, namun bertujuan untuk kesejahteraan perusahaan dan seluruh bagian yang ada di dalam perusahaan. Hal ini sejalan dengan Prosocial Behavior Theory yang menjelaskan bahwa tindakan yang dilakukan oleh seseorang dalam suatu organisasi tidak hanya bertujuan untuk kepentingan pribadi, namun juga untuk kepentingan seluruh bagian yang ada dalam organisasi dan whistleblowing merupakan salah satu bentuk dari perilaku prososial (Brief \& Motowidlo, 1986). Hasil ini sejalan juga dengan Theory of Planned Behaviour (TPB) yang menjelaskan terjadinya perilaku dapat diidentifikasi dengan niat. Niat dianggap sebagai faktor yang memengaruhi sebuah perilaku (Ajzen, 1991).

\section{Retaliasi rendah dan retaliasi tinggi pada kondisi tingkat keseriusan pelanggaran tinggi, anonymous reporting channel}

Hipotesis $3\left(\mathrm{H}_{3}\right)$ dalam penelitian adalah membandingkan antara grup 5 dengan grup 6 manakah grup yang memiliki rata-rata lebih tinggi. Perlakuan pada grup 5 adalah terdapat tingkat keseriusan pelanggaran tinggi, anonymous reporting channel, dan retaliasi rendah. Sedangkan perlakuan pada grup 6 adalah terdapat tingkat keseriusan pelanggaran tinggi, anonymous reporting channel, dan retaliasi tinggi.

Probabilitas antara grup 5 dan 6 (Tabel 4.7) memiliki nilai 0,034 lebih kecil dari signifikansi 0,05. Jika dilihat dari rata-rata (Tabel 4.8) masing-masing grup adalah 8,21 untuk grup 5 dan 6,53 
untuk grup 6. Hasil tersebut menunjukkan adanya perbedaan namun tidak terlalu signifikan dari kedua grup. Artinya antara grup 5 dan grup 6 keduanya memiliki keefektifan yang berbeda dalam mendorong whistleblowing, yang mana grup 5 lebih efektif dibandingkan grup 6. Selain itu, dari hasil rata-rata menunjukkan bahwa grup 5 memiliki nilai yang lebih tinggi dibandingkan grup 6 yaitu 8,21 > 6,53. Berdasarkan hasil ini maka dapat disimpulkan bahwa $\mathrm{H}_{3}$ diterima, artinya bahwa dalam kondisi tingkat keseriusan pelanggaran tinggi, anonymous reporting channel, dan retaliasi rendah niat melakukan whistleblowing akan lebih tinggi dibandingkan pada kondisi tingkat keseriusan pelanggaran tinggi, anonymous reporting channel, dan retaliasi tinggi. Adanya anonymous reporting channel dan retaliasi rendah akan memberikan rasa aman bagi pelapor untuk melaporkan tindakan pelanggaran karena mereka mengetahui bahwa identitasnya akan dirahasiakan dan adanya tindakan disipliner yang dilakukan oleh perusahaan terhadap pelaku retaliasi.

Adanya kondisi seperti pada uji hipotesis 3, maka dapat diketahui bahwa tujuan seseorang melaporkan tindakan pelanggaran bukan untuk mencari keuntungan pribadi, namun bertujuan untuk kesejahteraan perusahaan dan seluruh bagian yang ada di dalam perusahaan. Hasil penelitian pada $\mathrm{H}_{3}$ sejalan dengan Prosocial Behavior Theory yang menjelaskan bahwa tindakan yang dilakukan oleh seseorang dalam suatu organisasi tidak hanya bertujuan untuk kepentingan pribadi, namun juga untuk kepentingan seluruh bagian yang ada dalam organisasi dan whistleblowing merupakan salah satu bentuk dari perilaku prososial (Brief \& Motowidlo, 1986). Hasil ini sejalan juga dengan Theory of Planned Behaviour (TPB) yang menjelaskan terjadinya perilaku dapat diidentifikasi dengan niat. Niat dianggap sebagai faktor yang memengaruhi sebuah perilaku (Ajzen, 1991). Dari hasil penelitian ini maka dapat dilihat bahwa seseorang akan tetap memiliki niat untuk melaporkan tindakan pelanggaran dalam kondisi terdapat retaliasi rendah maupun tinggi dan terdapat kondisi keseriusan pelanggaran tinggi, serta anonymous reporting channel

Hasil uji hipotesis 3 ini didukung oleh adanya penelitian terdahulu seperti penelitian oleh Kaplan dkk. (2012), Jenkel dan Haen (2012), Johansson dan Carey (2015), Utami dkk. (2020), Putri (2016), Harahap dkk. (2020) yang menyatakan bahwa adanya anonymous reporting channel dapat meningkatkan niat individu untuk melakukan whistleblowing. Didukung juga penelitian Mesmer-Magnus dan Viswesvaran (2005), Liyanarachchi dan Newdick (2009), Manafe (2015), Dhamija dan Rai (2017), Yang dan Xu (2020) yang memberikan hasil bahwa tingkat retaliasi berpengaruh terhadap niat individu melakukan whistleblowing.

\section{Retaliasi rendah dan retaliasi tinggi pada kondisi tingkat keseriusan pelanggaran tinggi, non- anonymous reporting channel terhadap niat melakukan whistleblowing}

Hipotesis $4\left(\mathrm{H}_{4}\right)$ dalam penelitian adalah membandingkan antara grup 7 dengan grup 8 manakah grup yang memiliki rata-rata lebih tinggi. Perlakuan pada grup 7 adalah terdapat tingkat keseriusan pelanggaran tinggi, non-anonymous reporting channel, dan retaliasi rendah. Sedangkan pada perlakuan pada grup 8 adalah terdapat tingkat keseriusan tinggi, non-anonymous reporting channel, dan retaliasi tinggi.

Probabilitas antara grup 7 dan 8 (Tabel 4.7) memiliki nilai 0,829 lebih besar dari signifikansi 0,05. Jika dilihat dari rata-rata (Tabel 4.8) masing-masing grup adalah 6,40 untuk grup 7 dan 5,64 untuk grup 8. Hasil tersebut menunjukkan tidak adanya perbedaan yang signifikan dari kedua grup yang berarti antara grup 7 dan grup 8 keduanya memiliki keefektifan yang sama dalam mendorong whistleblowing. Selain itu, dari hasil rata-rata menunjukkan bahwa grup 7 memiliki nilai yang lebih tinggi dibandingkan grup 8 yaitu $6,40>5,64$ namun perbedaan tersebut tidak terlalu tinggi. Berdasarkan hasil ini maka dapat disimpulkan bahwa $\mathrm{H}_{4}$ ditolak, artinya tidak ada perbedaan yang signifikan dalam kondisi tingkat keseriusan pelanggaran tinggi, non-anonymous reporting channel, dan retaliasi rendah dibandingkan pada kondisi tingkat keseriusan tinggi, non-anonymous reporting channel, dan retaliasi tinggi.

Hasil uji hipotesis 4 menunjukkan bahwa dalam kondisi terdapat retaliasi rendah maupun retaliasi tinggi, tingkat keseriusan pelanggaran tinggi, dan non-anonymous reporting channel individu akan tetap termotivasi untuk melaporkan tindakan pelanggaran. Adanya kondisi seperti pada uji hipotesis 4, maka dapat diketahui bahwa tujuan seseorang melaporkan tindakan pelanggaran bukan untuk mencari keuntungan pribadi, namun bertujuan untuk kesejahteraan 
perusahaan dan seluruh bagian yang ada di dalam perusahaan. Hal ini sejalan dengan Prosocial Behavior Theory yang menjelaskan bahwa tindakan yang dilakukan oleh seseorang dalam suatu organisasi tidak hanya bertujuan untuk kepentingan pribadi, namun juga untuk kepentingan seluruh bagian yang ada dalam organisasi dan whistleblowing merupakan salah satu bentuk dari perilaku prososial (Brief \& Motowidlo, 1986). Hasil ini sejalan juga dengan Theory of Planned Behaviour (TPB) yang menjelaskan terjadinya perilaku dapat diidentifikasi dengan niat. Niat dianggap sebagai faktor yang memengaruhi sebuah perilaku (Ajzen, 1991).

\section{KESIMPULAN}

Berdasarkan data yang telah diuji, maka dapat diambil beberapa kesimpulan. Pertama, adanya retaliasi rendah dan retaliasi tinggi pada kondisi tingkat keseriusan pelanggaran rendah, dan anonymous reporting channel memiliki keefektifan yang sama dalam meningkatkan niat seseorang melaporkan tindakan pelanggaran. Kedua, adanya retaliasi rendah dan retaliasi tinggi pada kondisi tingkat keseriusan pelanggaran rendah, dan non-anonymous reporting channelmemiliki keefektifan yang sama dalam meningkatkan niat seseorang melaporkan tindakan pelanggaran yang diketahuinya. Ketiga, adanya retaliasi rendah dan retaliasi tinggi pada kondisi tingkat keseriusan pelanggaran tinggi, dan anonymous reporting channel memiliki keefektifan yang berbeda dalam meningkatkan niat seseorang melaporkan tindakan pelanggaran yang diketahuinya. Kondisi tingkat keseriusan pelanggaran tinggi, anonymous reporting channel, dan retaliasi rendah memiliki skor yang lebih tinggi dalam mendorong whistleblowing dibandingkan dalam kondisi terdapat tingkat keseriusan pelanggaran tinggi, anonymous reporting channel, dan retaliasi tinggi. Artinya dalam kondisi tingkat keseriusan pelanggaran tinggi, anonymous reporting channel, dan retaliasi rendah lebih efektif dalam meningkatkan niat seseorang untuk melaporkan tindakan pelanggaran. Adanya anonymous reporting channeldan retaliasi rendah akan memberikan rasa aman bagi pelapor untuk melaporkan tindakan pelanggaran karena mereka mengetahui bahwa identitasnya akan dirahasiakan dan adanya tindakan disipliner yang dilakukan oleh perusahaan terhadap pelaku retaliasi. Keempat, adanya retaliasi rendah dan retaliasi tinggi pada kondisi tingkat keseriusan pelanggaran tinggi, dan non-anonymous reporting channel memiliki keefektifan yang sama dalam meningkatkan niat seseorang melaporkan tindakan pelanggaran yang diketahuinya.

Hasil penelitian ini diharapkan dapat memberikan kontribusi bagi ilmu pengetahuan dan dapat menjadi referensi untuk penelitian selanjutnya. Selain itu dapat dijadikan saran dan referensi bagi perusahaan baik di sekor swasta maupun pemerintahan untuk membuat kebijakan yang dapat memotivasi karyawan dan atau masyarakat untuk melaporkan tindakan pelanggaran. Dengan semakin banyak perusahaan dan atau pemerintah yang menerapkan whistleblowing system dengan baik maka diharapkan kedepannya semakin banyak masyarakat yang menyadari untuk melaporkan tindakan pelanggaran yang mereka ketahui kepada pihak berwenang. Terpenting dari hasil penelitian ini menunjukkan bahwa adanya anonymous reporting channel sangat menentukan niat seseorang untuk melaporkan tindakan pelanggaran dibandingkan adanya non-anonymous reporting channel. Seseorang akan merasa lebih aman apabila identitasnya dirahasiakan oleh perusahaan ketika melaporkan tindakan pelanggaran. Adanya saluran pelaporan anonim ini menjadi bagian penting dalam suatu perusahaan untuk memberikan motivasi kepada karyawan agar berperilaku jujur dan melaporkan tindakan pelanggaran yang diketahuinya. Kemudian seseorang lebih termotivasi untuk melakukan whistleblowing dalam kondisi retaliasi rendah dibandingkan retaliasi tinggi. Oleh sebab itu, tindakan disipliner perlu dilakukan kepada pelaku retaliasi. Adanya tindakan disipliner kepada pelaku retaliasi akan mengurangi kekhawatiran pelapor pelanggaran (whistleblower) terhadap adanya retaliasi tersebut.

Penelitian ini memiliki beberapa keterbatasan yaitu pada pengambilan responden yang terbatas hanya mahasiswa Akuntansi FEB UMY angkatan 2018. Hal ini dikarenakan terbatasnya waktu dan tempat saat penelitian dilakukan. Penelitian selanjutnya disarankan dapat memperluas obyek penelitian dengan mengambil sampel dari beberapa universitas atau karyawan yang sudah bekerja. Penelitian ini hanya menguji pengaruh pada variabel tingkat keseriusan pelanggaran, 
reporting channel, dan retaliasi terhadap niat melakukan whistleblowing. Penelitian selanjutnya disarankan dapat menambahkan atau mengganti dengan variabel lainnya seperti pengaruh insentif, status pelaku pelanggaran, keadilan, dan lain-lain yang dapat mempengaruhi niat seseorang untuk melakukan whistleblowing.

\section{DAFTAR PUSTAKA}

Ajzen, I. (1991). The theory of planned behavior. Organizational Behavior and Human Decision Processes, 50(2), 179-211. https://doi.org/10.1016/0749-5978(91)90020-t

Aliyah, S. (2015). Analisis Faktor-Faktor yang Mempengaruhi Minat Pegawai Dalam Melakukan Tindakan Whistle-Blowing. Jurnal Dinamika Ekonomi \& Bisnis, 12(2), 173-189. Diakses dari https://ejournal.unisnu.ac.id/JDEB/article/view/370

Andon, P., Free, C., Jidin, R., Monroe, G. S., \& Turner, M. J. (2016). The Impact of Financial Incentives and Perceptions of Seriousness on Whistleblowing Intention. Journal of Business Ethics, 151(1), 165-178. https://doi.org/10.1007/s10551-016-3215-6

Assari, L., \& Dwita, S. (2020). Pengaruh Jalur Pelaporan Dan Retaliasi Terhadap Niat Seseorang Melakukan Whistleblowing. Jurnal Eksplorasi Akuntansi, 2(4), 3610-3627. https://doi.org/10.24036/jea.v2i4.308

Ayers, S., \& Kaplan, S. E. (2005). Wrongdoing by Consultants: An Examination of Employees? Reporting Intentions. Journal of Business Ethics, 57(2), 121-137. https://doi.org/10.1007/s10551-004-4600-0

Bagustianto, R., \& Nurkholis. (2015). Faktor-Faktor yang Mempengaruhi Minat Pegawai Negeri Sipil (PNS) Untuk Melakukan Tindakan Whistleblowing (Studi Pada PNS BPK RI). Jurnal Ekonomi dan Keuangan, 19(2), 276-295. Diakses dari https://jimfeb.ub.ac.id/index.php/jimfeb/article/view/1436

Bouville, M. (2007). Whistle-Blowing and Morality. Journal of Business Ethics, 81(3), 579-585. https://doi.org/10.1007/s10551-007-9529-7

Brief, A. P., \& Motowidlo, S. J. (1986). Prosocial Organizational Behaviors. The Academy of Management Review, 11(4), 710. https://doi.org/10.2307/258391

Cassematis, P. G., \& Wortley, R. (2012). Prediction of Whistleblowing or Non-reporting Observation: The Role of Personal and Situational Factors. Journal of Business Ethics, 117(3), 615-634. https://doi.org/10.1007/s10551-012-1548-3

Christy, T., \& Utami, I. (2020). Ethical Climate, Seriousness of Wrongdoing, Personal Characteristics and Whistleblowing-Intention. Proceedings of the Proceedings of The First International Conference on Financial Forensics and Fraud, ICFF, 13-14 August 2019, Bali, Indonesia. https://doi.org/10.4108/eai.13-8-2019.2294264

CNN Indonesia. (2019). Sulap Lapkeu, Mantan Dirut Hanson International Didenda Rp5 M. https://www.cnnindonesia.com/ekonomi/20190809145515-92-419879/sulap-lapkeu-mantandirut-hanson-international-didenda-rp5-m (Diakses pada 2 Juni 2020)

Della, R. N., Rodiah, S., \& Azmi, Z. (2020). Faktor-faktor yang Mempengaruhi Niat dan Prilaku Whistleblowing Karyawan Alfamart di Pekanbaru. Jurnal Akuntansi Dan Ekonomika, 1O(1), 21-30. https://doi.org/10.37859/jae.v10i1.1894.

Dhamija, S., \& Rai, S. (2017). Role of retaliation and value orientation in whistleblowing intentions. Asian Journal of Business Ethics, 7(1), 37-52. https://doi.org/10.1007/s13520-017-0078-6

Dianingsih, D. H., \& Pratolo, S. (2018). Analisis Faktor-Faktor Yang Memengaruhi Intensi Pegawai Negeri Sipil (PNS) Untuk Melakukan Tindakan Whistleblowing : Studi Empiris pada Badan Pemeriksa Keuangan RI dan Pemerintah Kota serta Kabupaten di Daerah Istimewa Yogyakarta. Reviu Akuntansi Dan Bisnis Indonesia, 2(1), 51-63. https://doi.org/10.18196/rab.020120

Dozier, J. B., \& Miceli, M. P. (1985). Potential Predictors of Whistle-Blowing: A Prosocial Behavior Perspective. Academy of Management Review, 10(4), 823-836. https://doi.org/10.5465/amr.1985.4279105 
Effendi, A., \& Nuraini, N. (2019). Pengaruh Perlindungan Hukum, Orientasi Etika Idealisme, Orientasi Etika Relativisme Dan Retaliasi Terhadap Intensi Whistleblowing (Survei Pada Mahasiswa Universitas Negeri Di Provinsi Aceh). Jurnal Ilmiah Mahasiswa Ekonomi Akuntansi, 4(3), 504-519. https://doi.org/10.24815/jimeka.v4i3.12586

Guthrie, C. P., \& Taylor, E. Z. (2016). Whistleblowing on Fraud for Pay: Can I Trust You? SSRN Electronic Journal. https://doi.org/10.2139/ssrn.2555712

Hanif, R. A., \& Odiatma, F. (2017). Pengaruh personal cost reporting, status wrong doer dan tingkat keseriusan kesalahan terhadap whistleblowing intention. Jurnal Akuntansi Keuangan Dan Bisnis, 1O(1), 11-20. Diakses dari https://jurnal.pcr.ac.id/index.php/jakb/article/view/979

Harahap, H. F., Misra, F., \& Firdaus, F. (2020). Pengaruh Jalur Pelaporan dan Komitmen Religius terhadap Niat Melakukan Whistleblowing: Sebuah Studi Eksperimen. Jurnal Ilmiah Akuntansi, 5(1), 130-150. https://doi.org/10.23887/jia.v5i1.24289

Hartomo, G. (2019). Kronologi Kasus Laporan Keuangan Garuda Indonesia Hingga Kena Sanksi. Diakses dari https://economy.okezone.com/read/2019/06/28/320/2072245/kronologi-kasuslaporan-keuangan-garuda-indonesia-hingga-kena-sanksi

Iqbal, M., Mukhtaruddin, M., \& Abukosim, A. (2019). Pengaruh Identitas Profesional, Locus of Commitment, Dan Intensitas Moral Terhadap Intensi Auditor Untuk Melakukan Tindakan Whistleblowing (Studi Kasus Pada Kantor Akuntan Publik Sumatera Bagian Selatan). AKUNTABILITAS: Jurnal Penelitian dan Pengembangan Akuntansi, 12(1), 15-28. https://doi.org/10.29259/ja.v12i1.9305

Jenkel, I., \& Haen, J. J. (2012). Influences on Students' Decisions to Report Cheating: A Laboratory Experiment. Journal of Academic Ethics, 10(2), 123-136. https://doi.org/10.1007/s10805-0129154-7

Johansson, E., \& Carey, P. (2015). Detecting Fraud: The Role of the Anonymous Reporting Channel. Journal of Business Ethics, 139(2), 391-409. https://doi.org/10.1007/s10551-015$\underline{2673-6}$

Kaplan, S. E., Pany, K., Samuels, J. A., \& Zhang, J. (2009). An Examination of the Effects of Procedural Safeguards on Intentions to Anonymously Report Fraud. Auditing: A Journal of Practice \& Theory, 28(2), 273-288. https://doi.org/10.2308/aud.2009.28.2.273

Kaplan, S. E., Pany, K., Samuels, J., \& Zhang, J. (2012). An examination of anonymous and nonanonymous fraud reporting channels. Advances in Accounting, 28(1), 88-95. https://doi.org/10.1016/j.adiac.2012.02.008

Kenny, K., Fotaki, M., \& Scriver, S. (2018). Mental Heath as a Weapon: Whistleblower Retaliation and Normative Violence. Journal of Business Ethics, 160(3), 801-815. https://doi.org/10.1007/s10551-018-3868-4.

Komite Nasional Kebijakan Governance. (2008). Pedoman Sistem Pelaporan Pelanggaran-SPP (Whistleblowing System-WBS). $\quad$ http://www.knkg-indonesia.org/dokumen/PedomanPelaporan-Pelanggaran-Whistleblowing-System-WBS.pdf

Latan, H., Chiappetta Jabbour, C. J., \& Lopes de Sousa Jabbour, A. B. (2019). To Blow or Not to Blow the Whistle: The Role of Rationalization in the Perceived Seriousness of Threats and Wrongdoing. Journal of Business Ethics, 169(3), 517-535. https://doi.org/10.1007/s10551019-04287-5

Lestari, R., \& Yaya, R. (2017). Whistleblowing Dan Faktor-Faktor Yang Mempengaruhi Niat Melaksanakannya Oleh Aparatur Sipil Negara. Jurnal Akuntansi, 21(3), 336. https://doi.org/10.24912/ja.v21i3.265

Liyanarachchi, G., \& Newdick, C. (2009). The Impact of Moral Reasoning and Retaliation on Whistle-Blowing: New Zealand Evidence. Journal of Business Ethics, 89(1), 37-57.

Manafe, M. W. N. (2015). Pengaruh Penalaran Moral, Retaliasi dan Gender Terhadap Kecenderungan Whistleblowing Internal. Wahana Jurnal Ekonomi, Manajemen, Dan Akuntansi, $18(2), \quad 113-123 . \quad$ Diakses dari http://jurnalwahana.aaykpn.ac.id/index.php/wahana/article/view/106 
Mesmer-Magnus, J. R., \& Viswesvaran, C. (2005). Whistleblowing in Organizations: An Examination of Correlates of Whistleblowing Intentions, Actions, and Retaliation. Journal of Business Ethics, 62(3), 277-297. https://doi.org/10.1007/s10551-005-0849-1

Miceli, M. P., \& Near, J. P. (1985). Characteristics of organizational climate and perceived wrongdoing associated with whistle-blowing decisions. Personnel Psychology, 38(3), 525-544. https://doi.org/10.1111/j.1744-6570.1985.tb00558.x

Nawawi, A., \& Salin, A. S. A. P. (2018). Whistle blowing intentions - evidence from Malaysian PLC. International Journal of Law and Management, 60(5), 1111-1125. https://doi.org/10.1108/IJLMA-04-2017-0096

Near, J. P., \& Miceli, M. P. (2012). Organizational Dissidence: The Case of Whistle-Blowing. Citation Classics from the Journal of Business Ethics, 153-172. https://doi.org/10.1007/97894-007-4126-3_8

Nugraha, T. (2017). Pengaruh Komitmen Profesional, Lingkungan Etika, SIfat MAcchiavellian, dan Personal Cost terhadap Intensi Whistleblowing dengan Retaliasi sebagai Variabel Moderating. JOM Fekon, 4(1), 2030-2044. Diakses dari https://jom.unri.ac.id/index.php/JOMFEKON/article/view/13446

Park, H., Blenkinsopp, J., Oktem, M. K., \& Omurgonulsen, U. (2007). Cultural Orientation and Attitudes Toward Different Forms of Whistleblowing: A Comparison of South Korea, Turkey, and the U.K. Journal of Business Ethics, 82(4), 929-939. https://doi.org/10.1007/s10551-0079603-1

Poluakan, M. J., Saerang, D. P. E., \& Lambey, R. (2017). Analisis Persepsi Atas Faktor-Faktor Yang Berpengaruh Terhadap Keinginan Seseorang Menjadi Whistleblower (Studi Kasus Pada Mahasiswa Jurusan Akuntansi Fakultas Ekonomi Dan Bisnis Universitas Sam Ratulangi). Jurnal EMBA: Jurnal Riset Ekonomi, Manajemen, Bisnis Dan Akuntansi, 5(2), 2695-2705. Diakses dari https://ejournal.unsrat.ac.id/index.php/emba/article/view/17109

Pope, K. R., \& Lee, C. C. (2013). Could the Dodd-Frank Wall Street Reform and Consumer Protection Act of 2010 be Helpful in Reforming Corporate America? An Investigation on Financial Bounties and Whistle-Blowing Behaviors in the Private Sector. Journal of Business Ethics, 112(4), 597-607. https://doi.org/10.1007/s10551-012-1560-7

Putri, C. (2016). Pengaruh Jalur Pelaporan dan Tingkat Religiusitas terhadap Niat Seseorang Melakukan Whistleblowing. Journal of Accounting and Investment, 17(1), 42-52. Diakses dari https://journal.umy.ac.id/index.php/ai/article/view/1364.

Robinson, S. N., Robertson, J. C., \& Curtis, M. B. (2012). The Effects of Contextual and Wrongdoing Attributes on Organizational Employees' Whistleblowing Intentions Following Fraud. Journal of Business Ethics, 106(2), 213-227. https://doi.org/10.1007/s 10551-011-0990Y

Sartika, D., \& Mulyani, F. (2020). Pengaruh Sifat Machiavellian, Lingkungan Etika, Komitmen Organisasi, dan Tingkat Keseriusan Kecurangan Terhadap Niat Melakukan Whistleblowing (Studi Empiris pada BPKAD di Kota Padang). Menara Ilmu, 14(1), 24-39. Diakses dari https://jurnal.umsb.ac.id/index.php/menarailmu/article/view/1863

Seifert, D. L., Sweeney, J. T., Joireman, J., \& Thornton, J. M. (2010). The Influence of Organizational Justice on Accountant Whistleblowing. Accounting, Organizations and Society, 35(7), 707-717. https://doi.org/10.1016/j.aos.2010.09.002

Sutrisni, D., \& Coryanata, I. (2018). Faktor-faktor yang mempengaruhi minat pengelola keuangan melakukan tindakan whistleblowing. Jurnal Akuntansi, 8(1), 41-53. https://doi.org/10.33369/j.akuntansi.8.1.41-54

Theotama, G. (2020). Retaliation, Seriousness of Wrongdoing, and Whistleblowing: An Experimental Study in Internal Governmental Auditor. Proceedings of The First International Conference on Financial Forensics and Fraud, ICFF, 13-14 August 2019, Bali, Indonesia, 110. https://doi.org/10.4108/eai.13-8-2019.2294250

Utami, N. M. M. A., Irianto, G., \& Prihatiningtias, Y. W. (2020). Analyzing the effect of financial reward, personal cost and reporting channel on whistleblowing intentions utilizing an 
experimental study. International Journal of Research in Business and Social Science, 9(2), 125-132. https://doi.org/10.20525/ijrbs.v9i2.614

Wijayanti, D. M., \& Yandra, F. P. (2020). The Role of Incentives, Emotional Connection, and Organizational Justice in Establishing an Effective Whistleblowing System: An Experimental Study. Jurnal Dinamika Akuntansi dan Bisnis, 7(1), 51-68. https://doi.org/10.24815/jdab.v7i1.14178

Winardi, R. D. (2013). The Influence of Individual and Situational Factors on Lower-Level Civil Servants' Whistle-Blowing Intention in Indonesia. Journal of Indonesian Economy and Business, 28(3), 361-376. Diakses dari https://iiap.ub.ac.id/index.php/jiap/article/view/684

Yang, L., \& Xu, R. (2020). The effects of retaliation on whistleblowing intentions in China banking industry. Journal of Accounting \& Organizational Change, 16(2), 215-235. https://doi.org/10.1108/jaoc-05-2019-0049

Zamzani, A.H., Ira, S., \& Mahmudah, H. (2019). Whistleblowing Intention: A Study of Situation Factors. International Journal of Economics and Management Studies, 6(12), 132-140. https://doi.org/10.14445/23939125/ijems-v6i12p115

Zhuang, J. (2003). Whistle-blowing \& peer reporting : a cross-cultural comparison of Canadians and Chinese. Tesis Magister. Diakses dari https://opus.uleth.ca/handle/10133/600 